\title{
High MET expression is an adverse prognostic factor in patients with triple-negative breast cancer
}

\author{
F Zagouri ${ }^{1,7}$, Z Bago-Horvath ${ }^{2,7}$, F Rössler ${ }^{2}$, A Brandstetter ${ }^{1}$, R Bartsch ${ }^{3}$, C A Papadimitriou ${ }^{4}$, \\ C Dimitrakakis ${ }^{5}$, A Tsigginou ${ }^{5}$, I Papaspyrou ${ }^{6}$, A Giannos $^{5}$, M-A Dimopoulos ${ }^{4}$ and M Filipits ${ }^{*}, 1$
}

${ }^{1}$ Institute of Cancer Research, Department of Medicine I, Comprehensive Cancer Center, Medical University of Vienna, Vienna, Austria; ${ }^{2}$ Department of Pathology, Comprehensive Cancer Center, Medical University of Vienna, Vienna, Austria; ${ }^{3}$ Division of Oncology, Department of Medicine I, Comprehensive Cancer Center, Medical University of Vienna, Vienna, Austria; ${ }^{4}$ Department of Clinical Therapeutics, Alexandra Hospital, Medical School, University of Athens, Athens, Greece; ${ }^{5}$ Department of Obstetrics and Gynaecology, Alexandra Hospital, Medical School, University of Athens, Athens, Greece and 'Department of Pathology, Alexandra Hospital, Medical School, University of Athens, Athens, Greece

Background: The mesenchymal-epithelial transition (MET) pathway is frequently altered in tumours. The purpose of our study was to determine the prognostic value of tumour MET expression levels in patients with triple-negative breast cancer (TNBC), in order to strengthen the rationale for targeted therapy of TNBC using MET inhibitors.

Methods: We determined expression of MET in formalin-fixed paraffin-embedded surgical specimens of TNBC by immunohistochemistry. Recurrence-free and overall survival was analysed with Cox models adjusted for clinical and pathological factors.

Results: Immunostaining for MET was classified as high in 89 of 170 (52\%) tumours. MET expression was more frequently observed in $\mathrm{G} 3$ carcinomas $(P=0.02)$ but was not significantly associated to any of the other clinical or pathological parameters. High MET expression predicted shorter survival of the patients. Multivariate Cox proportional hazards regression analyses identified MET to be an independent prognostic factor for recurrence (adjusted hazard ratio (HR) for recurrence 3.43; 95\% confidence interval (Cl) $1.65-7.12 ; P=0.001$ ) and death (adjusted HR for death 3.74; 95\% $\mathrm{Cl} 1.65-8.46 ; P=0.002$ ).

Conclusion: These results provide further evidence that the MET pathway could be exploited as a target for TNBC.

Triple-negative breast cancers (TNBCs) are characterised by the lack of expression of oestrogen receptor, progesterone receptor, and human epidermal growth factor receptor 2 (HER2; Dent et al, 2007). These cancers occur in approximately $20 \%$ of all patients with breast cancer and are associated with an unfavourable prognosis (Haffty et al, 2006). Patients with TNBC derive no benefit from endocrine therapy or HER2-targeted trastuzumab, because they lack the appropriate targets for these drugs. Current standard treatment is a combination of therapies such as surgery, radiation, and chemotherapy with novel agents in clinical trials for this indication. Knowledge of molecular biomarker associated with prognosis may help to devise new treatment strategies to improve the clinical outcome of TNBC.

A potential candidate biomarker is the mesenchymalepithelial transition factor (MET), a receptor tyrosine kinase, which has a key role in cell survival, growth, angiogenesis, and metastasis (Gherardi et al, 2012). MET and its physiological ligand, the hepatocyte growth factor (HGF) or scatter factor (SF), are required for normal mammalian development and have an important role in epithelialmesenchymal interactions during organ morphogenesis (Gherardi et al, 2012).

\footnotetext{
${ }^{*}$ Correspondence: Dr M Filipits; E-mail: martin.filipits@meduniwien.ac.at
}

${ }^{7}$ These authors contributed equally to this work.

Received 31 October 2012; revised 20 December 2012; accepted 7 January 2013; published online 19 February 2013 
The MET and HGF/SF are significantly overexpressed relative to normal tissue in a variety of carcinomas including lung, breast, colorectal, head and neck, and renal carcinomas (Sierra and Tsao, 2011). In addition, $M E T$ amplification has been reported in gastric cancer, colorectal cancer, gliomas, and breast cancer (Wullich et al, 1994; Di Renzo et al, 1995). In a recent study, amplification of the $M E T$ gene was assessed in patients with early stage breast cancer (Gonzalez-Angulo et al, 2012). MET copy number elevations were observed in $8 \%$ of breast cancers and were more likely to occur in patients with triple receptor-negative disease $(P=0.019)$. Moreover, patients with tumours harbouring an elevated MET copy number tended to have worse 5-year recurrence-free survival (RFS; $P=0.06$ ). As a result of its key function in cellular processes, MET is currently under investigation as a potential target for anticancer therapy in several types of human solid tumours (Gherardi et al, 2012).

The purpose of this study was to determine the prognostic value of tumour MET expression in patients with TNBC, in order to strengthen the rationale for targeted therapy of TNBC using MET inhibitors.

\section{PATIENTS AND METHODS}

Patients. Tumours negative for oestrogen receptor (cutoff $<10 \%$ positive tumour cells), progesterone receptor (cutoff $<10 \%$ positive tumour cells), and HER2 $(0,1+$, or $2+$ on immunohistochemistry and/or normal gene copy number by fluorescence in situ hybridisation) were classified as TNBC. We did not include further markers such as basal cytokeratins and/or EGFR that may identify a group of tumours that have a distinct adverse prognosis within the TNBC subgroup and that overlap with basal-like breast cancers (Tischkowitz et al, 2007).

Adequate formalin-fixed, paraffin-embedded tumour blocks, clinical history, and follow-up data from 83 cases of histologically confirmed patients diagnosed with TNBC between 1998 and 2009 were identified from the Department of Obstetrics and Gynaecology, Alexandra Hospital, Medical School, University of Athens, Athens, Greece. In addition, 87 tumour blocks of TNBC patients diagnosed between 1999 and 2003 from the Department of Pathology, Medical University of Vienna, Vienna, Austria were included.

Clinical information (including the patient's age, menopausal status, tumour size, lymph node status, tumour grade, and histology) and primary treatment (including surgery, radiotherapy, and chemotherapy) was extracted from the medical records. Exclusion criteria were: none-TNBC, in situ lesions, family history of breast cancer, inadequate tissue, and not signed informed consent.

Written informed consent was obtained by all subjects participating in the study. The study is in accordance with the Helsinki Declaration and has been approved by the local Institutional Review Boards.

Tumour block collection. For the current research project, the participating pathologists were asked to provide a representative formalin-fixed, paraffin-embedded tumour block from each patient. All tumour specimens were obtained at the time of surgery before adjuvant therapy. Paraffin blocks were stored at room temperature and were identified only by an identification number. A haematoxylin/eosin-stained section of each tumour block was prepared and used for pathologic confirmation of present TNBC. Further $4-\mu \mathrm{m}$ sections were obtained for the immunohistochemical analysis.

Immunostaining for MET. Immunohistochemistry was performed and evaluated in an ISO-certified lab at the Department of Medicine I, Medical University of Vienna by means of a standard protocol.

Briefly, tissue sections were deparaffinized and rehydrated. To reduce nonspecific background staining, slides were incubated in
$0.3 \% \mathrm{H}_{2} \mathrm{O}_{2}$ for $10 \mathrm{~min}$. For epitope retrieval, specimens were heated for $10 \mathrm{~min}$ in $10 \mathrm{~mm}$ citrate buffer $(\mathrm{pH}$ 6.0) in a pressure cooker. After incubation with Ultra V Block (UltraVision LP detection system, Lab Vision Corporation, Thermo Fisher Scientific Inc., Pittsburgh, MA, USA) for $5 \mathrm{~min}$ at room temperature to block background staining, the tissues were incubated for $30 \mathrm{~min}$ at room temperature with a rabbit monoclonal antibody specific for MET (CONFIRM anti-Total c-MET, SP44, ready-to-use, Ventana, Oro Valley, AZ, USA). Antibody binding was detected by means of the UltraVision LP detection system according to the manufacturer's recommendations (Lab Vision Corporation). Colour development was performed with 33 -diaminobenzidine and counterstain with haematoxylin. Sections of head and neck cancer specimens known to express MET served as positive controls (Perisanidis et al, 2012).

Expression of MET was examined blinded to clinical data of the patients. At least 100 tumour cells per case were evaluated. Immunostaining was classified based on membrane staining intensity and percentage of MET-positive tumour cells. Staining intensity was scored as 0 (absent), 1 (weak) and 2 (moderate), 3 (strong). For comparison with clinical parameters and survival, expression levels of MET were dichotomised into 'high' and 'low' expression. In order to be classified as high, tumour sections had to have moderate or strong membrane staining in equal or $>50 \%$ of invasive tumour cells (Dziadziuszko et al, 2012; Oliner et al, 2012).

Statistical analyses. The primary end point of our study was RFS. Overall survival was analysed as a secondary endpoint. Assumed a 5 -year RFS rate of $65 \%$ for MET-high patients and $90 \%$ for MET-low patients, the estimated power for 170 patients is $98 \%$ for detecting a $25 \%$ absolute RFS difference at 5 years with a two-sided type I error of 5\% (assuming that marker-positive and markernegative patients are equally distributed).

Baseline data according to MET protein expression status were compared in univariate analyses using the $\chi^{2}$ test. The MannWhitney $U$-test was used for continuous variables. Survival time was defined as the period between the date of surgery and the date of death of any cause (overall survival) or the period between the date of surgery and date of first local/distant recurrence or last follow-up (RFS). Patients who died before experiencing disease recurrence were censored at their date of death in the RFS analysis. Survival rates were estimated by means of the Kaplan-Meier method. Differences between survival curves were analysed by means of the log-rank test. The independent prognostic value of MET was studied with Cox models, which were adjusted for age (as a continuous variable), tumour size (T1, T2, T3, or T4), lymph node status (N0, N1, N2, or N3), and tumour grade (G1, G2, or G3). All reported $P$-values are two sided. All analyses were performed with the use of IBM SPSS Statistics software, version 20.0 (SPSS, IBM Corporation, Armonk, NY, USA).

\section{RESULTS}

A total of 170 tumour blocks were of sufficient amount and quality for sectioning. Protein expression of MET was evaluated in these 170 specimens and all further statistical analyses were performed on this patient population. We assessed tumour MET expression using standard immunohistochemistry. Immunostaining of MET was membranous and partly cytoplasmatic. Only membrane staining was used for evaluation. Figure 1 shows representative examples of MET immunostaining. Comparisons of MET expression with clinical parameters including survival of the patients were performed with MET expression as a dichotomised variable classified as high or low.

Of the 170 tumours, 89 (52\%) showed high MET expression. Table 1 compares the characteristics of the patients according to 

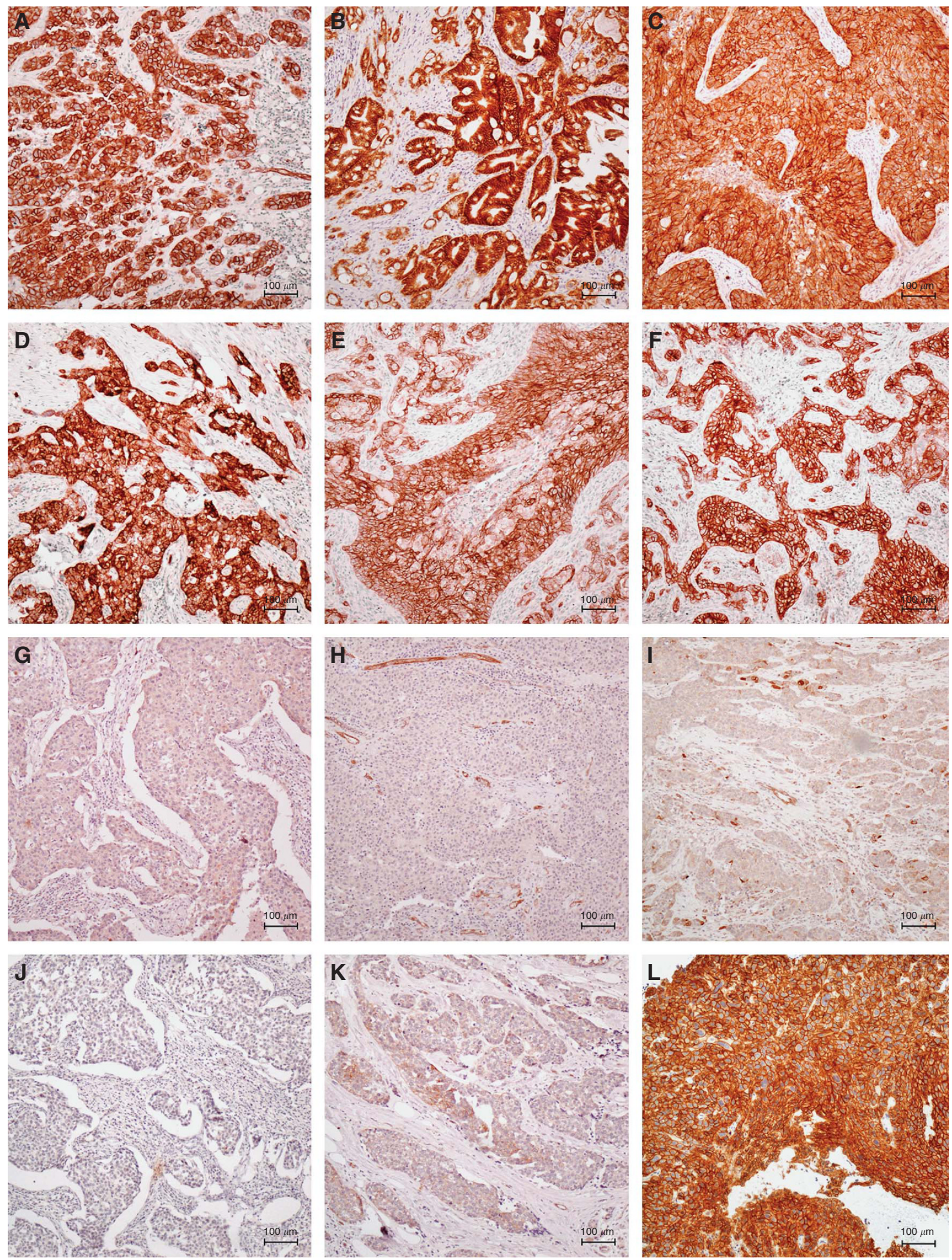

Figure 1. Examples of MET immunostaining. Figure 1 shows high MET expression of TNBCs (A-F), low MET expression of TNBCs (G-K), and high MET expression of a head and neck cancer specimen that was used as positive control (L). Bar $=100 \mu \mathrm{m}$.

MET expression in univariate analyses. High MET expression was more frequently observed in $\mathrm{G} 3$ carcinomas $(P=0.02)$ but was not significantly correlated to any of the other clinical or pathological parameters (Table 1).

At a median follow-up of 7.4 years $(95 \%$ confidence interval (CI) 6.5-8.3 years), 45 of 170 (27\%) patients experienced a local/distant recurrence and 38 of 170 (22\%) patients had died. In univariate survival analyses, tumour size (hazard ratio (HR) for recurrence 1.75 ; 95\% CI 1.21-2.54; $P=0.003$ ), and lymph node status (HR for recurrence $1.46 ; 95 \%$ CI $1.13-1.88 ; P=0.004)$ were significantly associated with RFS (Table 2). Tumour size (HR for death 1.58; 95\% CI $1.04-2.40 ; \quad P=0.03)$ correlated significantly with overall survival. The 5-year RFS of all 170 patients was $77 \%$. Patients with MET-high tumours had a significantly shorter RFS than those with MET-low tumours (Table 2, Figure 2A). Five-year RFS was $67 \%$ for patients with MET-high tumours whereas it was $89 \%$ for patients with MET-low tumours $(P<0.001$; Figure $2 \mathrm{~A})$. The 5-year overall survival rate of all 170 patients was $83 \%$. Five-year overall survival was $76 \%$ in patients with MET-high tumours and $92 \%$ in patients with MET-low tumours ( $P=0.001$; Figure $2 \mathrm{~B})$. 


\begin{tabular}{|c|c|c|c|c|}
\hline Characteristic & $\mathbf{N}=170$ & $\begin{array}{l}\text { Patients } \\
\text { with MET- } \\
\text { low } \\
\text { tumours } \\
\mathbf{N}=\mathbf{8 1}\end{array}$ & $\begin{array}{l}\text { Patients } \\
\text { with } \\
\text { MET-high } \\
\text { tumours } \\
\mathbf{N}=\mathbf{8 9}\end{array}$ & $\boldsymbol{P}$-value \\
\hline $\begin{array}{l}\text { Age at surgery } \\
\text { Median, years } \\
\text { Range, years }\end{array}$ & $\begin{array}{c}59 \\
23-85\end{array}$ & $\begin{array}{c}61 \\
23-85\end{array}$ & $\begin{array}{c}57 \\
30-80\end{array}$ & 0.09 \\
\hline $\begin{array}{l}\text { Menopausal status } \\
\text { Premenopausal } \\
\text { Postmenopausal }\end{array}$ & $\begin{array}{r}51(30 \%) \\
119(70 \%)\end{array}$ & $\begin{array}{l}20(25 \%) \\
61(75 \%)\end{array}$ & $\begin{array}{l}31(35 \%) \\
58(65 \%)\end{array}$ & 0.15 \\
\hline $\begin{array}{l}\text { Tumour size } \\
\text { T1 } \\
\text { T2 } \\
\text { T3 } \\
\text { T4 }\end{array}$ & $\begin{array}{c}79(47 \%) \\
81(48 \%) \\
6(4 \%) \\
4(2 \%)\end{array}$ & $\begin{array}{c}43(53 \%) \\
32(40 \%) \\
3(4 \%) \\
3(4 \%)\end{array}$ & $\begin{array}{c}36(40 \%) \\
49(55 \%) \\
3(3 \%) \\
1(1 \%)\end{array}$ & 0.19 \\
\hline $\begin{array}{l}\text { Lymph node status } \\
\text { N0 } \\
\text { N1 } \\
\text { N2 } \\
\text { N3 }\end{array}$ & $\begin{array}{l}97(57 \%) \\
41(24 \%) \\
18(11 \%) \\
14(8 \%)\end{array}$ & $\begin{array}{c}45(56 \%) \\
18(22 \%) \\
11(14 \%) \\
7(9 \%)\end{array}$ & $\begin{array}{c}52(58 \%) \\
23(26 \%) \\
7(8 \%) \\
7(8 \%)\end{array}$ & 0.65 \\
\hline $\begin{array}{l}\text { Tumour grade } \\
\text { G1 } \\
\text { G2 } \\
\text { G3 }\end{array}$ & $\begin{array}{c}2(1 \%) \\
33(19 \%) \\
135(79 \%)\end{array}$ & $\begin{array}{c}1(1 \%) \\
23(28 \%) \\
57(70 \%)\end{array}$ & $\begin{array}{c}1(1 \%) \\
10(11 \%) \\
78(88 \%)\end{array}$ & 0.02 \\
\hline $\begin{array}{l}\text { Histology } \\
\text { Ductal } \\
\text { Lobular } \\
\text { Other }\end{array}$ & $\begin{array}{c}151 \text { (89\%) } \\
7 \text { (4\%) } \\
12(7 \%)\end{array}$ & $\begin{array}{c}73(90 \%) \\
4(5 \%) \\
4(5 \%)\end{array}$ & $\begin{array}{c}78(88 \%) \\
3(3 \%) \\
8(9 \%)\end{array}$ & 0.53 \\
\hline $\begin{array}{l}\text { Chemotherapy } \\
\text { Anthracycline- } \\
\text { based } \\
\text { Anthracycline- } \\
\text { and taxane-based } \\
\text { Other } \\
\text { None }\end{array}$ & $\begin{array}{l}54(32 \%) \\
71(42 \%) \\
25(15 \%) \\
20(12 \%)\end{array}$ & $\begin{array}{l}19(24 \%) \\
40(49 \%) \\
13(16 \%) \\
9(11 \%)\end{array}$ & $\begin{array}{l}35(39 \%) \\
31(35 \%) \\
12(14 \%) \\
11(12 \%)\end{array}$ & 0.12 \\
\hline $\begin{array}{l}\text { Radiotherapy } \\
\text { Yes } \\
\text { No }\end{array}$ & $\begin{array}{r}139(82 \%) \\
31(18 \%)\end{array}$ & $\begin{array}{l}66(82 \%) \\
15(19 \%)\end{array}$ & $\begin{array}{l}73(82 \%) \\
16(18 \%)\end{array}$ & 0.93 \\
\hline $\begin{array}{l}\text { Cohort } \\
\text { Athens } \\
\text { Vienna }\end{array}$ & $\begin{array}{l}83(49 \%) \\
87(51 \%)\end{array}$ & $\begin{array}{l}45 \text { (56\%) } \\
36(44 \%)\end{array}$ & $\begin{array}{l}38 \text { (43\%) } \\
51 \text { (57\%) }\end{array}$ & 0.09 \\
\hline
\end{tabular}

The independent effect of MET expression on RFS and overall survival was assessed by Cox proportional hazards regression models adjusted for age, tumour size, lymph node status, and tumour grade (Table 2). In these analyses, MET expression was significantly associated with RFS (adjusted HR for recurrence 3.43; 95\% CI 1.65-7.12; $P=0.001$ ) and overall survival (adjusted HR for death 3.74 ; $95 \%$ CI $1.65-8.46 ; P=0.002$; Table 2). Thus, MET is an independent prognostic factor in patients with TNBC.

\section{DISCUSSION}

In our study, we demonstrated that tumour MET expression status is an independent prognostic factor in patients with TNBC. Recurrence-free and overall survival was shorter in TNBC patients with high tumour MET expression than in patients with low tumour MET expression. Our observation is consistent with several previous reports, which demonstrated a poor prognostic value of high MET expression in breast cancer (Ghoussoub et al, 1998; Camp et al, 1999; Nakopoulou et al, 2000; Tolgay Ocal et al, 2003; Lengyel et al, 2005). In the current analysis, we observed high MET protein expression in $52 \%$ of TNBCs, which is higher compared with other reports (15-28\%; Ghoussoub et al, 1998; Camp et al, 1999; Nakopoulou et al, 2000; Tolgay Ocal et al, 2003; Lengyel et al, 2005). However, the other reports included all subtypes of breast cancer and were not restricted to TNBC. Interestingly, in a recent report a higher frequency of $M E T$ gene copy number elevations was observed in TNBC compared with other breast cancer subtypes, which is in line with our findings (Gonzalez-Angulo et al, 2012).

The MET signalling pathway is frequently altered in human cancers and represents an attractive target for anticancer therapy (Sierra and Tsao, 2011). Several studies have shown that genetic abnormalities, which lead to aberrant MET signalling can cause human cancer. When mutated MET was used to replace endogenous MET in the mouse germ line, these mutations cause a variety of tumours including sarcomas, lymphomas, and carcinomas (Graveel et al, 2004). When expressed in the mammary gland, they induce basal-like breast carcinomas (Ponzo et al, 2009). In addition, activating mutations of MET are clonally selected for during the metastasis of human head and neck cancers, as their frequency increased from $2 \%$ in the primary tumours to $50 \%$ in the metastases, and this suggests that aberrant MET is associated with progression and metastasis (Di Renzo et al, 2000). Finally, in several human solid tumours including gastric, oesophageal, and breast cancer, amplification of MET (on chromosome 7q31) can occur (Houldsworth et al, 1990; Rege-Cambrin et al, 1992; Gonzalez-Angulo et al, 2012). These data provide additional rationale to target the MET signalling pathway for cancer therapy.

MET is inhibited by specific small molecule inhibitors or monoclonal antibodies (Gherardi et al, 2012). They inhibit proliferation and induce apoptosis in cell lines derived from several human cancers (Sierra and Tsao, 2011). The clinical relevance of MET inhibitors is currently under investigation, with tivantinib and onartuzumab being the main representatives of MET inhibitors (Gherardi et al, 2012).

Tivantinib (ARQ 197) is an oral, selective, non-adenosine triphosphate competitive MET inhibitor. Data from phase I trials demonstrated that tivantinib as monotherapy (Rosen et al, 2011; Yap et al, 2011) as well as combined with erlotinib (Goldman et al, 2012) is well tolerated with significant antitumour activity. On account of these favourable results, a phase II trial has been conducted evaluating the combination of erlotinib plus tivantinib in previously treated non-small-cell lung cancer patients (Sequist et al, 2011). Although this study did not meet its primary endpoint, evidence of activity was demonstrated, especially among patients with KRAS mutations and a phase III trial is currently ongoing (Scagliotti et al, 2012).

Onartuzumab (MetMAb, OA-5D5) is a one-armed monoclonal antibody developed to bind to and inhibit MET receptor tyrosine kinase. This agent holds great promise in diseases thought to be driven by aberrant MET signalling. Data from phase I trials demonstrate that onartuzumab is well tolerated in patients with advanced solid tumours (Moss et al, 2010a, b), with fatigue, peripheral oedema, and hypoalbuminemia being the most frequent treatment-related adverse events (Moss et al, 2010b). Moreover, its combination with bevacizumab seems to be generally safe and well tolerated (Moss et al, 2010a). In addition, in a randomised phase II trial of onartuzumab in combination with erlotinib in patients with advanced NSCLC demonstrated an overall survival benefit from the combination in MET immunohistochemistry-positive tumours; the addition of onartuzumab to erlotinib in these patients 
Table 2. Cox proportional hazard models

\begin{tabular}{|c|c|c|c|c|c|c|}
\hline Variable & $\begin{array}{l}\text { Hazard ratio for } \\
\text { recurrence }\end{array}$ & $95 \% \mathrm{Cl}$ & $\boldsymbol{P}$-value & $\begin{array}{l}\text { Hazard ratio } \\
\text { for death }\end{array}$ & $95 \% \mathrm{Cl}$ & $P$-value \\
\hline \multicolumn{7}{|c|}{ Univariate analyses } \\
\hline $\begin{array}{l}\text { Age } \\
\text { Tumour size } \\
\text { Nodal status } \\
\text { Tumour grade } \\
\text { MET }\end{array}$ & $\begin{array}{l}0.99 \\
1.75 \\
1.46 \\
2.04 \\
3.38\end{array}$ & $\begin{array}{l}0.97-1.02 \\
1.21-2.54 \\
1.13-1.88 \\
0.88-4.73 \\
1.67-6.83\end{array}$ & $\begin{array}{c}0.61 \\
0.003 \\
0.004 \\
0.10 \\
0.001\end{array}$ & $\begin{array}{l}1.02 \\
1.58 \\
1.29 \\
1.43 \\
3.42\end{array}$ & $\begin{array}{l}0.99-1.04 \\
1.04-2.40 \\
0.97-1.72 \\
0.65-3.15 \\
1.57-7.46\end{array}$ & $\begin{array}{l}0.25 \\
0.03 \\
0.08 \\
0.38 \\
0.002\end{array}$ \\
\hline \multicolumn{7}{|c|}{ Multivariate analyses } \\
\hline $\begin{array}{l}\text { Age } \\
\text { Tumour size } \\
\text { Nodal status } \\
\text { Tumour grade } \\
\text { MET }\end{array}$ & $\begin{array}{l}1.00 \\
1.55 \\
1.54 \\
1.65 \\
3.43\end{array}$ & $\begin{array}{l}0.98-1.02 \\
1.03-2.32 \\
1.17-2.02 \\
0.68-4.02 \\
1.65-7.12\end{array}$ & $\begin{array}{l}0.90 \\
0.03 \\
0.002 \\
0.27 \\
0.001\end{array}$ & $\begin{array}{l}1.02 \\
1.37 \\
1.28 \\
1.11 \\
3.74\end{array}$ & $\begin{array}{l}0.99-1.05 \\
0.88-2.13 \\
0.94-1.73 \\
0.48-2.54 \\
1.65-8.46\end{array}$ & $\begin{array}{l}0.18 \\
0.16 \\
0.11 \\
0.81 \\
0.002\end{array}$ \\
\hline
\end{tabular}

A

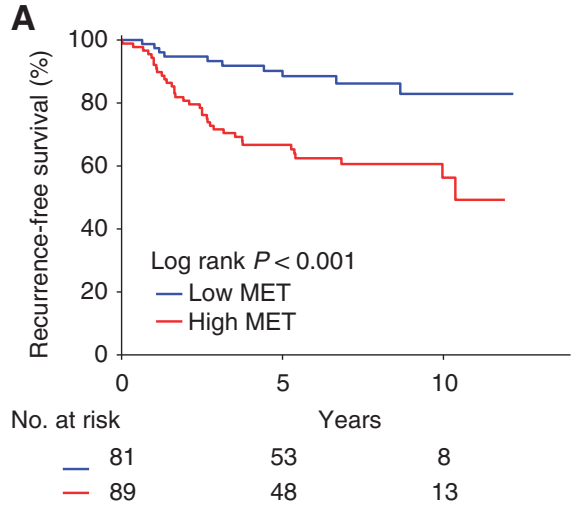

B

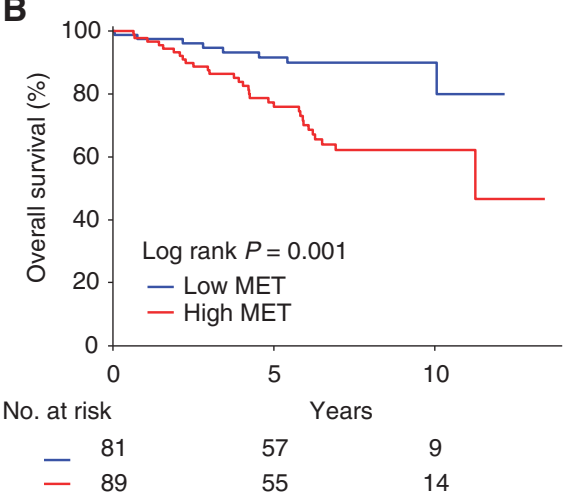

Figure 2. Kaplan-Meier estimates of the probability of survival. Figure 2 shows recurrence-free survival (A) and overall survival (B) of all 170 TNBC patients according to MET expression status.

significantly improved progression-free and overall survival, resulting in a near three-fold reduction in the risk of death (Spigel et al, 2011).

Currently, phase II and III clinical trials in a variety of malignancies including non-small cell lung cancer (ClinicalTrials.gov Identifier: NCT01456325, NCT01244191), colorectal cancer (ClinicalTrials.gov Identifier: NCT01418222, NCT01075048), gastrooesophageal cancer (ClinicalTrials.gov Identifier: NCT01590719), multiple myeloma (ClinicalTrials.gov Identifier: NCT01447914), prostate cancer (ClinicalTrials.gov Identifier: NCT01519414), and glioblastoma (ClinicalTrials.gov Identifier: NCT01632228) are ongoing. With regard to breast cancer, a phase II trial examining tivantinib in patients with recurrent or metastatic TNBC (ClinicalTrials.gov Identifier: NCT01575522) and a randomised phase II study evaluating the safety and efficacy of onartuzumab and/or bevacizumab in combination with paclitaxel in patients with metastatic TNBC (ClinicalTrials.gov Identifier: NCT01186991) are currently ongoing.

In conclusion, our findings suggest that MET is a prognostic marker in patients with TNBC. Thus, the MET pathway may be a potential target for therapy in patients with TNBC.

\section{ACKNOWLEDGEMENTS}

Flora Zagouri was supported by a research grant from the Hellenic Society of Medical Oncology (HeSMO).

\section{REFERENCES}

Camp RL, Rimm EB, Rimm DL (1999) Met expression is associated with poor outcome in patients with axillary lymph node negative breast carcinoma. Cancer 86(11): 2259-2265.

Dent R, Trudeau M, Pritchard KI, Hanna WM, Kahn HK, Sawka CA, Lickley LA, Rawlinson E, Sun P, Narod SA (2007) Triple-negative breast cancer: clinical features and patterns of recurrence. Clin Cancer Res 13(15 Pt 1): 4429-4434.

Di Renzo MF, Olivero M, Giacomini A, Porte H, Chastre E, Mirossay L, Nordlinger B, Bretti S, Bottardi S, Giordano S et al. (1995) Overexpression and amplification of the met/HGF receptor gene during the progression of colorectal cancer. Clin Cancer Res 1(2): 147-154.

Di Renzo MF, Olivero M, Martone T, Maffe A, Maggiora P, Stefani AD, Valente G, Giordano S, Cortesina G, Comoglio PM (2000) Somatic mutations of the MET oncogene are selected during metastatic spread of human HNSC carcinomas. Oncogene 19(12): 1547-1555.

Dziadziuszko R, Wynes MW, Singh S, Asuncion BR, Ranger-Moore J, Konopa K, Rzyman W, Szostakiewicz B, Jassem J, Hirsch FR (2012) Correlation between MET gene copy number by silver in situ hybridization and protein expression by immunohistochemistry in non-small cell lung cancer. J Thorac Oncol 7(2): 340-347.

Gherardi E, Birchmeier W, Birchmeier C, Vande Woude G (2012) Targeting MET in cancer: rationale and progress. Nat Rev Cancer 12(2): 89-103.

Ghoussoub RA, Dillon DA, D’Aquila T, Rimm EB, Fearon ER, Rimm DL (1998) Expression of c-met is a strong independent prognostic factor in breast carcinoma. Cancer 82(8): 1513-1520.

Goldman JW, Laux I, Chai F, Savage RE, Ferrari D, Garmey EG, Just RG, Rosen LS (2012) Phase 1 dose-escalation trial evaluating the combination 
of the selective MET (mesenchymal-epithelial transition factor) inhibitor tivantinib (ARQ 197) plus erlotinib. Cancer 118(23): 5903-5911.

Gonzalez-Angulo AM, Chen H, Karuturi MS, Chavez-Macgregor M, Tsavachidis S, Meric-Bernstam F, Do KA, Hortobagyi GN, Thompson PA, Mills GB, Bondy ML, Blumenschein Jr GR (2012) Frequency of mesenchymal-epithelial transition factor gene (MET) and the catalytic subunit of phosphoinositide-3-kinase (PIK3CA) copy number elevation and correlation with outcome in patients with early stage breast cancer. Cancer 119(1): 7-15.

Graveel C, Su Y, Koeman J, Wang LM, Tessarollo L, Fiscella M, Birchmeier C, Swiatek P, Bronson R, Vande Woude G (2004) Activating Met mutations produce unique tumor profiles in mice with selective duplication of the mutant allele. Proc Natl Acad Sci USA 101(49): 17198-17203.

Haffty BG, Yang Q, Reiss M, Kearney T, Higgins SA, Weidhaas J, Harris L, Hait W, Toppmeyer D (2006) Locoregional relapse and distant metastasis in conservatively managed triple negative early-stage breast cancer. J Clin Oncol 24(36): 5652-5657.

Houldsworth J, Cordon-Cardo C, Ladanyi M, Kelsen DP, Chaganti RS (1990) Gene amplification in gastric and esophageal adenocarcinomas. Cancer Res 50(19): 6417-6422.

Lengyel E, Prechtel D, Resau JH, Gauger K, Welk A, Lindemann K, Salanti G, Richter T, Knudsen B, Vande Woude GF, Harbeck N (2005) C-Met overexpression in node-positive breast cancer identifies patients with poor clinical outcome independent of Her2/neu. Int J Cancer 113(4): 678-682.

Moss RA, Bothos JG, Filvaroff E, Merchant M, Eppler S, Yu W, Harris K, Scott P, Mehnert JM, Patel PH (2010a) Phase Ib dose-escalation study of MetMAb, a monovalent antagonist antibody to the receptor MET, in combination with bevacizumab in patients with locally advanced or metastatic solid tumors. J Clin Oncol 28(suppl): abstr e13050.

Moss RA, Patel P, Bothos J, Peterson AC, Eppler S, Yu W (2010b) Complete results from phase I dose escalation study of MetMAb, a monovalent antagonist antibody to the receptor Met, dosed as single agent and in combination with bevacizumab in patients with advanced solid malignancies. Ann Oncol 21, viii165(Suppl. 168): abstract 504P.

Nakopoulou L, Gakiopoulou H, Keramopoulos A, Giannopoulou I, Athanassiadou P, Mavrommatis J, Davaris PS (2000) c-Met tyrosine kinase receptor expression is associated with abnormal beta-catenin expression and favourable prognostic factors in invasive breast carcinoma. Histopathology 36(4): 313-325.

Oliner KS, Tang R, Anderson A, Lan Y, Iveson T, Donehower RC, Jiang Y, Dubey S, Loh E (2012) Evaluation of MET pathway biomarkers in a phase II study of rilotumumab (R, AMG 102) or placebo (P) in combination with epirubicin, cisplatin, and capecitabine (ECX) in patients (pts) with locally advanced or metastatic gastric $(G)$ or esophagogastric junction (EGJ) cancer. J Clin Oncol 30(suppl): abstr 4005.

Perisanidis C, Wrba F, Brandstetter A, Kornek G, Mitchell D, Seemann R, Selzer E, Ewers R, Filipits M (2012) Impact of epidermal growth factor receptor, mesenchymal-epithelial transition factor, and insulin-like growth factor receptor 1 expression on survival of patients with oral and oropharyngeal cancer. Br J Oral Maxillofac Surg; e-pub ahead of print 11 August 2012; doi:10.1016/j.bjoms.2012.06.009.

Ponzo MG, Lesurf R, Petkiewicz S, O’Malley FP, Pinnaduwage D, Andrulis IL, Bull SB, Chughtai N, Zuo D, Souleimanova M, Germain D, Omeroglu A, Cardiff RD, Hallett M, Park M (2009) Met induces mammary tumors with diverse histologies and is associated with poor outcome and human basal breast cancer. Proc Natl Acad Sci USA 106(31): 12903-12908.

Rege-Cambrin G, Scaravaglio P, Carozzi F, Giordano S, Ponzetto C, Comoglio PM, Saglio G (1992) Karyotypic analysis of gastric carcinoma cell lines carrying an amplified c-met oncogene. Cancer Genet Cytogenet 64(2): 170-173.

Rosen LS, Senzer N, Mekhail T, Ganapathi R, Chai F, Savage RE, Waghorne C, Abbadessa G, Schwartz B, Dreicer R (2011) A phase I dose-escalation study of tivantinib (ARQ 197) in adult patients with metastatic solid tumors. Clin Cancer Res 17(24): 7754-7764.

Scagliotti GV, Novello S, Schiller JH, Hirsh V, Sequist LV, Soria JC, von Pawel J, Schwartz B, Von Roemeling R, Sandler AB (2012) Rationale and design of MARQUEE: a phase III, randomized, double-blind study of tivantinib plus erlotinib versus placebo plus erlotinib in previously treated patients with locally advanced or metastatic, nonsquamous, non-small-cell lung cancer. Clin Lung Cancer 13(5): 391-395.

Sequist LV, von Pawel J, Garmey EG, Akerley WL, Brugger W, Ferrari D, Chen Y, Costa DB, Gerber DE, Orlov S, Ramlau R, Arthur S, Gorbachevsky I, Schwartz B, Schiller JH (2011) Randomized phase II study of erlotinib plus tivantinib versus erlotinib plus placebo in previously treated non-small-cell lung cancer. J Clin Oncol 29(24): 3307-3315.

Sierra JR, Tsao MS (2011) c-MET as a potential therapeutic target and biomarker in cancer. Ther Adv Med Oncol 3(1 Suppl): S21-S35.

Spigel DR, Ervin TJ, Ramlau R, Daniel DB, Goldschmidt JH, Blumenschein GR, Krzakowski MJ, Robinet G, Clement-Duchene C, Barlesi F, Govindan R, Patel T, Orlov SV, Wertheim MS, Zha J, Pandita A, Yu W, Yauch RL, Patel PH, Peterson AC (2011) Final efficacy results from OAM4558g, a randomized phase II study evaluating MetMAb or placebo in combination with erlotinib in advanced NSCLC. J Clin Oncol 29(suppl): abstr 7505.

Tischkowitz M, Brunet JS, Begin LR, Huntsman DG, Cheang MC, Akslen LA, Nielsen TO, Foulkes WD (2007) Use of immunohistochemical markers can refine prognosis in triple negative breast cancer. BMC Cancer 7: 134.

Tolgay Ocal I, Dolled-Filhart M, D’Aquila TG, Camp RL, Rimm DL (2003) Tissue microarray-based studies of patients with lymph node negative breast carcinoma show that met expression is associated with worse outcome but is not correlated with epidermal growth factor family receptors. Cancer 97(8): 1841-1848.

Wullich B, Sattler HP, Fischer U, Meese E (1994) Two independent amplification events on chromosome 7 in glioma: amplification of the epidermal growth factor receptor gene and amplification of the oncogene MET. Anticancer Res 14(2A): 577-579.

Yap TA, Olmos D, Brunetto AT, Tunariu N, Barriuso J, Riisnaes R, Pope L, Clark J, Futreal A, Germuska M, Collins D, deSouza NM, Leach MO, Savage RE, Waghorne C, Chai F, Garmey E, Schwartz B, Kaye SB, de Bono JS (2011) Phase I trial of a selective c-MET inhibitor ARQ 197 incorporating proof of mechanism pharmacodynamic studies. J Clin Oncol 29(10): 1271-1279.

This work is published under the standard license to publish agreement. After 12 months the work will become freely available and the license terms will switch to a Creative Commons AttributionNonCommercial-Share Alike 3.0 Unported License. 